\title{
Influence of trematodes on the demography of Littorina saxatilis (Gastropoda: Prosobranchia: Littorinidae) in the White Sea
}

\author{
Inna M. Sokolova \\ White Sea Biological Station, Zoological Institute of the Russian Academy of Science, 199034 St. Petersburg, Russia
}

\begin{abstract}
Five populations of the rough winkle Littorina saxatilis (Olivi) with different levels of trematode infection were investigated in the White Sea, NW Russia: 2 control populations N1 and N2 (ca 5\% infection), 1 moderately infected population $M$ (ca 10 to $15 \%$ infection) and 2 heavily infected populations $\mathrm{H} 1$ and $\mathrm{H} 2$ (50 to $80 \%$ infection). Trematode prevalence was the lowest in snails collected from macrophytes, intermediate on gravel and highest on stone surfaces at all collection sites. The distribution of infection in different age groups of snails was random in the control populations, but prevalence increased with age in moderately and heavily infected populations. Demographic structure was variable. The following parameters were typical for all populations regardless of infection level: (1) total sex ratios were close to $1: 1$ or biased slightly towards females; (2) the relative abundance of males decreased with the age of snails; (3) no sex-specific ditterences in infection prevalence were found in any population; and (4) females became mature at 3 to 4 yr. However, the following demographic parameters showed significant differences that were correlated with trematode infection: (1) fewer juveniles were found in populations $\mathrm{H1}$ and $\mathrm{H} 2$, probably a result of reduced recruitment due to severe infection; and (2) fecundity of uninfected females increased with the increase in trematode infection at the collection sites and was the lowest in populations N1 and N2, intermediate in population M and the highest in population $\mathrm{H} 1$. These results suggest an adaptation that ensures periwinkle survival under conditions of heavy infection pressure.
\end{abstract}

KEY WORDS: Littorina saxatilis - Trematoda · Demography

\section{INTRODUCTION}

Demecology of intertidal gastropod molluscs has been intensively investigated for decades (Begon et al. 1989). The reasons for this interest include wide distribution of many gastropod species, their important role in intertidal benthic communities and the need to learn more about their population organization.

Littorina saxatilis (Olivi) is an abundant intertidal snail found on North Atlantic and Arctic shores and in the Mediterranean Sea (Matveeva 1974). Infection by larval trematodes is recognized as an important factor in the population dynamics of $L$. saxatilis (see Granovitch 1992). Because trematodes generally cause parasitic castration of infected snails (Hurd 1990) and thus have a direct effect on snail reproduction and population dynamics, trematode infection is unique in terms of its influence upon host population demography. The extent of this influence can be determined quantitatively and is dependent on parasite density in the host population.

Despite the important role that trematode infection has in host demography, it is often ignored in ecological studies. Papers that address the demography of littorinids with trematode prevalence are rare (James 1968a, b, Robson \& Williams 1971, Pohley 1976; see also Lauckner 1980 for review). Studies that examine host demographic structure in regard to the severity of infection are even less frequent. To our knowledge, only Granovitch \& Sergievsky (1990) have investigated the demography of periwinkles with various levels of infection. The present study was designed to provide more detailed information about the demographic structure of Littorina saxatilis in the White Sea and the effect that trematode parasites have on population structure of the periwinkles. 


\section{MATERIALS AND METHODS}

Sample collection and analysis. The work was carried out in Kandalaksha Bay of the White Sea (NW Russia) in 1990 and 1991 Five locations were studied (Table 1); 4 in Chupa Inlet (populations N1, N2, M. H1) and 1 in the North Archipelago region (population $\mathrm{H} 2$ ) (Fig. 1) Littonna saxatils is an ovoviviparous species without a planktonic dispersal stage (Matveeva 1974). Mobility of adult L. saxatilis is low (1 to $3 \mathrm{~m}$ ) (Janson 1983, A. I. Granovitch pers. comm.), therefore distances of $100 \mathrm{~m}$ appear to be effective barriers for the gene exchange between localities (Janson \& Ward 1984) Thus, each study site likely possesses its own distinct snail population.

Trematode prevalences at the 5 study sites had been previously determined (Granovitch 1990, pers. obs.). The populations from Maly Gorely Island (N1) and from Yushkovskaya Inlet of Siedny Island (N2) were characterized by low prevalences $(0$ to $5 \%)$ and were used as control sites in this study. The population from the headland between Seldyanaya and Kruglaya Inlets (M) was identified as moderately infected. Populations from Korga (a small islet submerged during high water) near Levin-Navolok (H1) and from the West Spit of the South Inlet of Ryazhkov island in Kandalaksha Nature Reserve (H2) are known to be heavlly infected (Fig. 1).

All study sites were located on sheltered coasts with salinity range of 20 to $25 \mathrm{ppt}$ (normal values in the White Sea) and possessed gently sloping intertıdal zones 15 to $20 \mathrm{~m}$ in width. Lower horizons $(5$ to $7 \mathrm{~m}$ width) were occupied by the macrophyte algae (mostly Ascophyllum nodosum and Fucus vesiculosus). Above the fucold belt the gravel and stone zones were situated. Small gravel and stone areas were also found within the fucoid belt

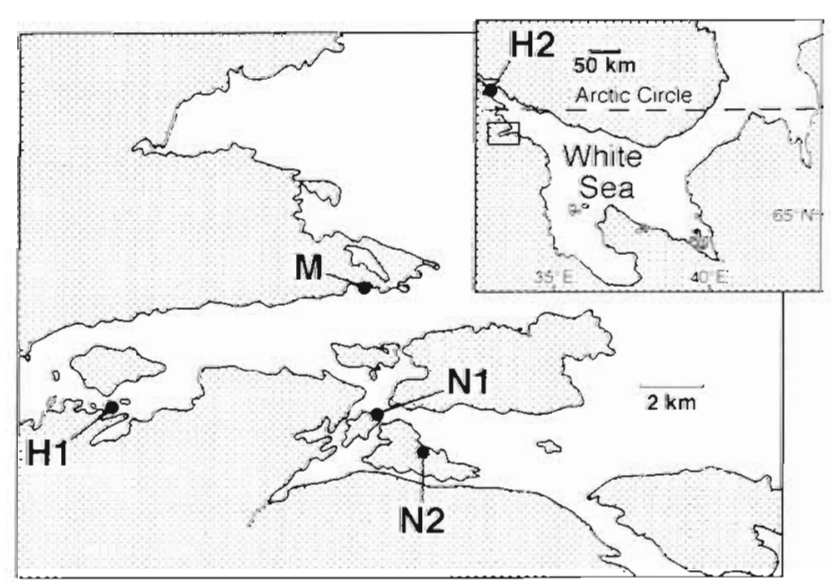

Fig 1 Location of study sites in the White Sea, NW Russia
Table 1 Littorina saxatilis. Collection dates, numbers of samples and density of snail population in 5 populations with low (N1, N2), intermediate $(\mathrm{M})$ and high $(\mathrm{H} 1, \mathrm{H} 2)$ infection prevalences in the $W$ hite Sea. Substrates: $F$, samples from macrophytes; $G$, gravel $S$, stone surfaces

\begin{tabular}{|c|c|c|c|c|}
\hline Population & $\begin{array}{c}\text { Date of } \\
\text { sampling } \\
(1990)\end{array}$ & & $\begin{array}{c}\text { No. of } \\
\text { samples } \\
\text { (areas of } 1 / 40 \mathrm{~m}^{2} \text { ) }\end{array}$ & $\begin{array}{l}\text { Population } \\
\text { density } \\
\text { (ind. } \mathrm{m}^{-2} \text { ) }\end{array}$ \\
\hline \multirow[t]{3}{*}{ N1 } & \multirow[t]{3}{*}{1 Aug } & F & 18 & 1515.6 \\
\hline & & G & 12 & 633.3 \\
\hline & & $\mathrm{S}$ & 6 & 1213.3 \\
\hline \multirow[t]{3}{*}{$\mathrm{N} 2$} & \multirow[t]{3}{*}{$24 \mathrm{Jul}$} & $F$ & 20 & 1.730 .0 \\
\hline & & G & 7 & 851.4 \\
\hline & & S & 12 & 623.3 \\
\hline \multirow[t]{3}{*}{$M$} & \multirow[t]{3}{*}{$12 \mathrm{Aug}$} & F & 10 & 1400.0 \\
\hline & & G & 9 & 1284.4 \\
\hline & & S & 12 & 1064.0 \\
\hline \multirow[t]{3}{*}{$\mathrm{H} 1$} & \multirow[t]{3}{*}{5 May } & F & 9 & 844.4 \\
\hline & & G & 8 & 640.0 \\
\hline & & $\mathrm{S}$ & 5 & 1664.0 \\
\hline \multirow[t]{3}{*}{$\mathrm{H} 2$} & \multirow[t]{3}{*}{$10 \mathrm{Aug}$} & $\mathrm{F}$ & 21 & 916.2 \\
\hline & & G & 5 & 984.0 \\
\hline & & S & 8 & 1070.0 \\
\hline
\end{tabular}

At each location, snails were collected at low tide from 3 substrate types: (1) the fucoid belt, (2) gravel and (3) stone surfaces. All samples were collected from a $1 / 40 \mathrm{~m}^{2}$ area each and placed into separate plastic bags. For the fucoid belt, all seaweeds were cut off and taken together with the upper layer ( 2 to $3 \mathrm{~cm}$ in depth) of underlying sediment. For the second substrate, the upper layer $(2$ to $3 \mathrm{~cm}$ ) of gravel was sampled. Snails from the stone surfaces were carefully hand-collected

In order to make the sampling representative, several samples were taken at each study site. Samples were collected 0.5 to $1 \mathrm{~m}$ apart (depending on width of the intertidal zone) between the spring low-tide level and lower supralittoral. All intertidal horizons were equally represented in the total of samples at each location The number of samples collected from each substrate type was proportional to the relative area occupied by the substrate (Table 1). As a result, a total of 78, 41 and 36 samples were collected from macrophyte algae. gravel and stone surfaces, respectively.

In the laboratory all periwinkles were sorted, shell diameter was measured and age of each mollusc recognized by annual growth checks was determined (these checks appear on the shell during long winters at the White Sea when the snails do not grow). In very few cases the age determination was difficult because of partial destruction of growth checks, so these molluscs were placed into age groups according to their size. All snalls greater than 1 yr of age were dissected using a binocular microscope in order to determine 
sex, fecundity (total number of embryos found in the brood pouch), presence or absence of trematode parthenites and to identify the species of trematode parasites present in the snail. A total of 4371 individuals of Littorina saxatilis were collected of which 2643 were dissected.

Because Sergievsky \& Granovitch (1989) and Granovitch (1990) showed that population density, age structure and infection may vary in different substrates, these parameters were estimated separately for each substrate type. Means, standard deviations, percentages and percent errors were calculated (Urbakh 1964). Sex ratios and infection prevalences in males and females were compared using Z-statistics (Fleiss 1989).

Determination of female fecundity. Data presented by Matveeva (1974) and personal preliminary observations showed that uninfected adult females of Littorina saxatilis contain embryos in the brood pouch throughout the year in the White Sea. However, there are considerable seasonal variations in fecundity of $L$. saxatilis. These variations were found to be synchronous for all age groups of females and study sites in Chupa Inlet (Sokolova unpubl.). The lowest fecundity of $L$. saxatilis was observed at the beginning (May to middle of June) and at the end (middle of September to November) of the reproduction period. In July and August fecundity was the highest in the studied populations (Sokolova unpubl.).

Location $\mathrm{H} 2$ was not sampled for determination of female fecundity because there were no data on seasonal changes in the numbers of embryos at this site.

Fecundity was determined as the total number of embryos (eggs, trochophore-like and veliger-like embryos and juveniles) found in the brood pouch of the female. Only uninfected gravid females from the fucoid samples were used for fecundity determination.

Fecundity of females in different populations was examined by ANOVA (Urbakh 1964). Three gradations of the infection level in the population of origin were used: low (in control populations), moderate (population $\mathrm{M}$ ) and high (population H1). It is worth noting that infection prevalences of females used for fecundity comparisons were always $0 \%$. Age of females was included in ANOVA as a covariate.

The relative reproductive contribution of different age groups of females was also determined for uninfected gravid females from the samples collected on fucoids. The contribution of infected gravid females to recruitment was very small $(<1 \%)$ because of their low fecundity and rare occurrence in the population studied. The relative contribution of a given age group was determined as follows:

$$
C_{1}=F_{i} \times 100 / F_{1}
$$

where $C_{i}$ is the contribution of females at age $i$ to the total embryo production $(\%), F_{1}$ is the number of embryos found in the brood pouches of gravid females of age group $i$, and $F_{i}$ is the total number of embryos found in females of all ages.

Population $\mathrm{H} 2$ was excluded from this analysis for the same reasons given above

\section{RESULTS}

\section{Population density}

This parameter varied greatly both within and between populations. At N1 and N2 population density was clearly higher in the fucoid zone (Table 1). In contrast, the snail density on the stone surfaces was nearly equal to ( $\mathrm{M}, \mathrm{H} 2$ ) or higher ( $\mathrm{H} 1)$ than that on the fucoids (Table 1).

\section{Age structure}

Differences in age structure were found between groups of snails inhabiting different substrates. In general, the most abundant age groups for all substrata in populations N1, N2 and M were 1 and 2 yr old snails (Figs. 2, $3 \& 4$ ). At $\mathrm{H} 1$ and $\mathrm{H} 2$ older age groups dominated (Fig. 2, $3 \& 4$ ). The results indicate that longevity varied in the different populations. At N1, N2 and $M$ the maximum longevity was 7 to $8 \mathrm{yr}$, whereas the oldest snails at $\mathrm{H} 1$ and $\mathrm{H} 2$ were 9 to $10 \mathrm{yr}$ old (Figs. 2, $3 \& 4$ ).

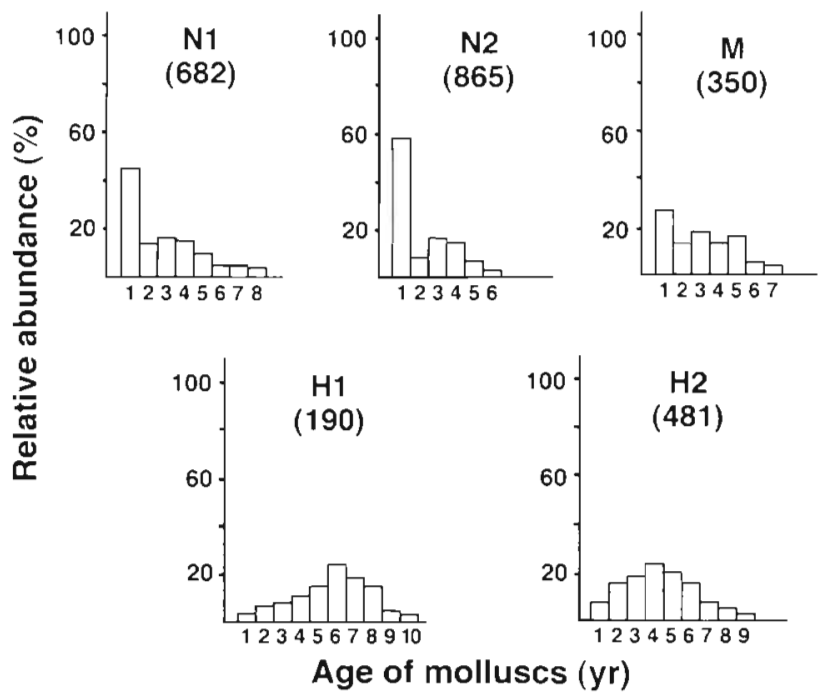

Fig. 2. Littorina saxatilis. Age structure in samples from fucoids in populations with low (N1, N2), intermediate (M) and high $(\mathrm{H} 1, \mathrm{H} 2)$ infection prevalences. Number of examined snails are given in parentheses 


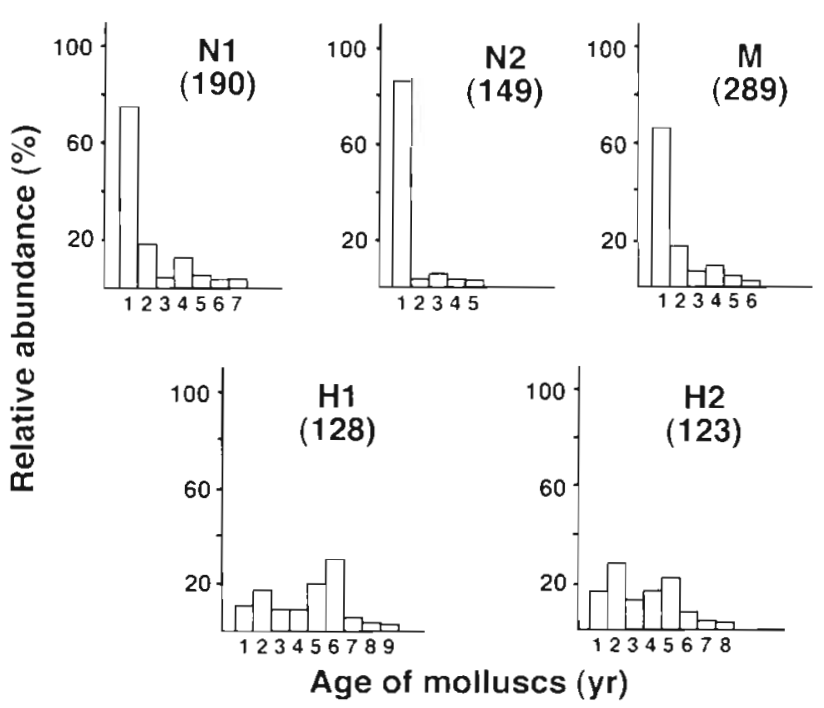

Fig. 3. Littorina saxatilis. Age structure in samples from gravel in populations with low (N1, N2), intermediate (M) and high $(\mathrm{H} 1, \mathrm{H} 2)$ infection prevalences. Number of examined snails are given in parentheses

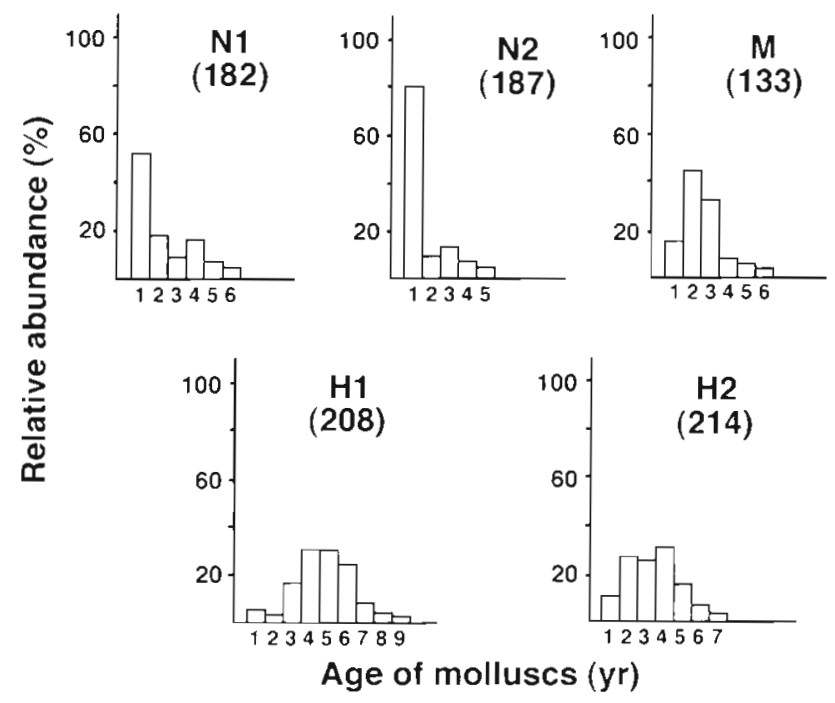

Fig. 4. Littorina saxatilis. Age structure in samples from stone surfaces in populations with low (N1, N2), intermediate (M) and high $\left(\mathrm{H}_{1}, \mathrm{H}_{2}\right)$ infection prevalences. Number of examined snails are given in parentheses

\section{Distribution of infection prevalence over substrata and in different age classes}

Preliminary study had shown that Littorina saxatilis is a host for 10 trematode species in the White Sea. Due to different life-cycle patterns, the parasites can be divided into 2 ecological groups (Granovitch 1990).
Table 2. Littorina saxatilis. Trematode infection prevalence $(\% \pm \mathrm{SE})$ in populations with low (N1, N2) . intermediate (M) and high $(\mathrm{H} 1, \mathrm{H} 2)$ infection levels in the White Sea. n: no. of dissected snails are given in parentheses. Lack of coincidence between the total pecentage of invasion and the sum of infection extensivities by the trematodes of groups A (microphallids of 'pygmaeus' group) and B (trematodes with free-living cercariae) is caused by the presence of double infections

\begin{tabular}{|c|c|c|c|c|}
\hline \multirow{2}{*}{$\begin{array}{l}\text { Popu- } \\
\text { lation }\end{array}$} & \multirow{2}{*}{$\begin{array}{l}\text { Trema- } \\
\text { tode }\end{array}$} & \multicolumn{2}{|r|}{ Substrate } & \multirow[b]{2}{*}{$\begin{array}{l}\text { Stone } \\
\text { surface }\end{array}$} \\
\hline & & Fucoids & Gravel & \\
\hline \multirow[t]{3}{*}{ N1 } & A & $0.3 \pm 0.26$ & 0 & $1.0 \pm 1.09$ \\
\hline & B & $1.3 \pm 0.57$ & $2.9 \pm 2.05$ & $2.2 \pm 1.54$ \\
\hline & Total & $\begin{array}{c}1.5 \pm 0.62 \\
(390)\end{array}$ & $\begin{array}{c}2.9 \pm 2.05 \\
(68)\end{array}$ & $\begin{array}{c}3.3 \pm 1.87 \\
(91)\end{array}$ \\
\hline \multirow[t]{3}{*}{ N2 } & A & $2.6 \pm 0.85$ & $4.2 \pm 4.08$ & $7.7 \pm 4.27$ \\
\hline & B & $1.4 \pm 0.64$ & 0 & \\
\hline & Total & $\begin{array}{c}4.0 \pm 1.05 \\
(350)\end{array}$ & $\begin{array}{c}4.2 \pm 4.08 \\
(24)\end{array}$ & $\begin{array}{c}7.7 \pm 4.27 \\
(39)\end{array}$ \\
\hline \multirow[t]{3}{*}{ M } & A & $5.5 \pm 1.32$ & $5.8 \pm 2.30$ & $10.0 \pm 2.86$ \\
\hline & B & $6.7 \pm 1.56$ & $3.9 \pm 1.91$ & $4.3 \pm 1.98$ \\
\hline & Total & $\begin{array}{c}12.1 \pm 2.04 \\
(256)\end{array}$ & $\begin{array}{c}9.7 \pm 2.92 \\
(103)\end{array}$ & $\begin{array}{c}13.6 \pm 3.27 \\
(113)\end{array}$ \\
\hline \multirow[t]{3}{*}{$\mathrm{H} 1$} & A & $56.8 \pm 3.61$ & $76.1 \pm 4.01$ & 100 \\
\hline & $B$ & $7.6 \pm 1.59$ & $4.4 \pm 1.93$ & $3.5 \pm 1.31$ \\
\hline & Total & $\begin{array}{c}57.3 \pm 3.61 \\
(188)\end{array}$ & $\begin{array}{c}77.9 \pm 3.90 \\
(114)\end{array}$ & $\begin{array}{c}100 \\
(198)\end{array}$ \\
\hline \multirow[t]{3}{*}{$\mathrm{H} 2$} & A & $47.5 \pm 2.39$ & $53.5 \pm 5.01$ & $94.5 \pm 1.74$ \\
\hline & B & $3.7 \pm 0.90$ & $1.0 \pm 1.00$ & $0.6 \pm 0.59$ \\
\hline & Total & $\begin{array}{c}51.1 \pm 2.39 \\
(438)\end{array}$ & $\begin{array}{c}54.5 \pm 5.00 \\
(99)\end{array}$ & $\begin{array}{c}94.8 \pm 1.69 \\
(172)\end{array}$ \\
\hline
\end{tabular}

Group A consists of trematodes without secondary dispersion (free-living cercariae) in the life cycle: microphallids of 'pygmaeus' species complex: Microphallus piriformes, $M$. pygmaeus, $M$. pseudopygmaeus and $M$. triangulatus, of which $M$. piriformes is the most common. Metacercariae of these closely related species develop in daughter sporocysts. The infection of the definitive host (common eider and some species of sea-gulls) occur without involvement of a second intermediate host (Dobrovolsky et al. 1983, Galaktionov \& Dobrovolsky 1984). It is worth noting that the pygmaeus' group accounts for the high infection levels in Littorina saxatilis populations, especially at $\mathrm{H} 1$ and $\mathrm{H} 2$ (Table 2).

Group B contains those trematodes with free-living cercariae: Podocotyle atomon, Notocotylus sp., Renicola sp., Himasthla sp., Cryptocotyle lingua, and Microphallus sp. Prevalences of group B trematodes are often lower than those of group A (Table 2).

All 10 species of trematodes were found in our study. Trematode prevalences were generally low $(<5 \%)$ in control populations from all substrata except in samples from N2 stone surfaces (Table 2). However, in this case 
Table 3. Littorina saxatilis. Distribution of the infection prevalence ( $\% \pm \mathrm{SE}$ ) over the age classes in populations with low (N1, N2), intermediate $(\mathrm{M})$ and high $(\mathrm{H} 1, \mathrm{H} 2)$ infection levels. No. of dissected snails for 0 and $100 \%$ values are given in parentheses. Substrates: F, fucoids; $G$, gravel; $S$, stone surface

\begin{tabular}{|c|c|c|c|c|c|c|c|c|}
\hline Population & Substrate & 2 & 3 & 4 & $\begin{array}{c}\text { Age of host (yr) } \\
5\end{array}$ & 6 & 7 & $>7$ \\
\hline N1 & $\begin{array}{l}F \\
G \\
S\end{array}$ & $\begin{array}{c}0(89) \\
0(30) \\
2.9 \pm 2.88\end{array}$ & $\begin{array}{c}0.9 \pm 1.00 \\
11.1 \pm 10.47 \\
0(14)\end{array}$ & $\begin{array}{c}2.7 \pm 1.54 \\
0(17) \\
4.2 \pm 4.09\end{array}$ & $\begin{array}{c}1.6 \pm 1.58 \\
0(7) \\
10.0 \pm 9.49\end{array}$ & $\begin{array}{c}0(10\} \\
25.0 \pm 21.65 \\
0(9)\end{array}$ & $\begin{array}{c}25.0 \pm 21.65 \\
0(1)\end{array}$ & $0(1)$ \\
\hline $\mathrm{N} 2$ & $\begin{array}{l}F \\
G \\
S\end{array}$ & $\begin{array}{c}2.6 \pm 1.82 \\
0(7) \\
8.3 \pm 7.96\end{array}$ & $\begin{array}{c}3.4 \pm 1.67 \\
0(11) \\
6.2 \pm 6.03\end{array}$ & $\begin{array}{c}5.6 \pm 2.22 \\
20.0 \pm 17.89 \\
9.1 \pm 8.67\end{array}$ & $\begin{array}{c}4.4 \pm 3.02 \\
0(1)\end{array}$ & $0(3)$ & & \\
\hline M & $\begin{array}{l}F \\
G \\
S\end{array}$ & $\begin{array}{l}4.3 \pm 2.99 \\
6.1 \pm 3.42 \\
3.6 \pm 2.51\end{array}$ & $\begin{array}{r}6.6 \pm 3.18 \\
8.3 \pm 7.96 \\
12.8 \pm 5.03\end{array}$ & $\begin{array}{l}10.2 \pm 3.94 \\
14.8 \pm 6.83 \\
45.5 \pm 15.01\end{array}$ & $\begin{array}{l}22.0 \pm 5.39 \\
10.0 \pm 9.49 \\
42.9 \pm 18.71\end{array}$ & $\begin{array}{l}23.1 \pm 8.27 \\
20.0 \pm 17.89 \\
0(1)\end{array}$ & $20.0 \pm 17.89$ & \\
\hline $\mathrm{H} 1$ & $\begin{array}{l}F \\
G \\
S\end{array}$ & $\begin{array}{c}7.7 \pm 7.39 \\
27.8 \pm 10.56 \\
100(5)\end{array}$ & $\begin{array}{c}37.5 \pm 12.10 \\
42.8 \pm 13.22 \\
100(28)\end{array}$ & $\begin{array}{c}78.9 \pm 9.36 \\
92.9 \pm 6.86 \\
100(60)\end{array}$ & $\begin{array}{c}70.4 \pm 8.95 \\
86.4 \pm 7.57 \\
100(59)\end{array}$ & $\begin{array}{c}53.6 \pm 7.78 \\
100(28) \\
100(33)\end{array}$ & $\begin{array}{c}69.7 \pm 8.00 \\
83.3 \pm 13.61 \\
100(10)\end{array}$ & $\begin{array}{c}55.0 \pm 7.87 \\
100(6) \\
100(3)\end{array}$ \\
\hline $\mathrm{H} 2$ & $\begin{array}{l}F \\
G \\
S\end{array}$ & $\begin{array}{l}20.6 \pm 4.90 \\
23.1 \pm 8.27 \\
87.0 \pm 4.58\end{array}$ & $\begin{array}{c}39.1 \pm 5.23 \\
43.7 \pm 12.40 \\
100(47)\end{array}$ & $\begin{array}{l}61.4 \pm 4.84 \\
71.4 \pm 8.37 \\
98.2 \pm 1.76\end{array}$ & $\begin{array}{c}63.9 \pm 4.88 \\
77.3 \pm 8.93 \\
100(25)\end{array}$ & $\begin{array}{l}59.3 \pm 6.69 \\
90.0 \pm 9.49 \\
91.7 \pm 7.96\end{array}$ & $\begin{array}{c}63.6 \pm 10.26 \\
66.7 \pm 27.21 \\
100(2)\end{array}$ & $\begin{array}{c}66.7 \pm 15.71 \\
0(1)\end{array}$ \\
\hline
\end{tabular}

sample size was small (Table 2), and the differences between the substrates was not significant $(p>0.05)$.

In the moderately infected population the prevalence of both ecological groups of trematodes in macrophyte and gravel substrates were similar ( $\mathrm{p}>$ 0.05 ) except that microphallids of the 'pygmaeus' were more common in snails from stone surfaces $(\mathrm{p}<0.05)$ (Table 2). In general, total prevalences were similar regardless of substrata (Table 2 ).

In heavily infected populations, the prevalences of trematodes with free-living cercariae were similar to those in population $M$ (Table 2). The large majority of infections in populations $\mathrm{H} 1$ and $\mathrm{H} 2$ were caused by group A trematodes (Table 2). Prevalences of group A infections in $\mathrm{H} 1$ and $\mathrm{H} 2$ populations, respectively, were 56.8 and $47.5 \%$ on macrophytes, 76.1 and $53.5 \%$ on gravel and 100 and $94.5 \%$ on stone surfaces. Thus, infection prevalences in populations $\mathrm{H} 1$ and $\mathrm{H} 2$ were 5 to 8 times higher than in population $M$ and 10 to 20 times higher than in population N1 and N2 (Table 2).

Because presence of mature parthenites of groups $\mathrm{A}$ and/or B similarly resulted in castration of the snail, the total prevalences of trematodes, regardless of the group, were used in the age-prevalence curves analysis.

A correlation between prevalences and age of periwinkles was not evident in populations $\mathrm{N} 1$ and $\mathrm{N} 2(\mathrm{p}>$ 0.05 ) (Table 3 ). In the moderately infected population, infection increased with snail age, although this tendency was not always significant (Table 3).

In populations $\mathrm{H} 1$ and $\mathrm{H} 2$, the age-prevalence relationship was influenced by substrata. On macrophytes, lowest prevalences were observed in 2 yr old snails, followed by marked increase in infection in 3 to 4 yr old periwinkles (Table 3). Trematode prevalences in greater than 4 years old snails were nearly equal to those of 4 yr old individuals (Table 3). A similar prevalence pattern was observed in snails collected from gravel (Table 3). Infection prevalences of 87 to $100 \%$ were observed in all groups of Littorina saxatilis collected from stone surfaces regardless of age (Table 3 ).

\section{Sex ratio}

Sex ratios in the studied populations approached 1:1 but, in general, more females than males were found (Table 4). A marked decrease in male frequency was observed in snails greater than 5 yr old (Fig. 5), so that females largely dominated the older age groups.

Table 4. Littorina saxatilis. Sex ratio $( \pm \mathrm{SE})$ in populations with low (N1, N2), intermediate (M) and high (H1, H2) infection prevalences. 'Significantly different from $50 \%(p<0.05)$

\begin{tabular}{|ccc|}
\hline Population & $\begin{array}{c}\text { Proportion of males } \\
(\%)\end{array}$ & $\begin{array}{c}\text { No. of snails } \\
\text { examined }\end{array}$ \\
\hline N1 & $45.2 \pm 2.13$ & 547 \\
N2 & $41.7 \pm 2.44$ & 410 \\
M & $45.3 \pm 2.29$ & 472 \\
H1 & $46.3 \pm 2.23$ & 500 \\
H2 & $38.3 \pm 1.83$ & 709 \\
\hline
\end{tabular}




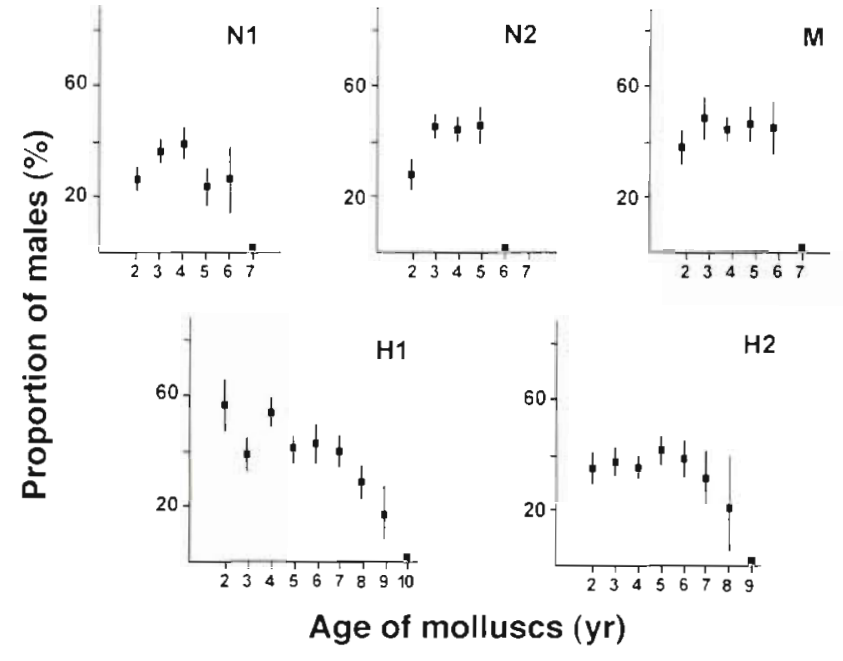

Fig. 5. Littorina saxatilis. Age-related alterations $( \pm$ SE) of sex ratio in populations with low $(\mathrm{N} 1, \mathrm{~N} 2$ ), intermediate (M) and high $(\mathrm{H} 1, \mathrm{H} 2)$ infection prevalences

\section{Sex-specific infection prevalence}

No differences in total prevalence were found between sexes in the populations studied (Table 5).

\section{Female reproductive condition}

The data on population density, relative quantity of adults, and trematode prevalence in snails from different substrata showed that more potential fertile snails are found in the fucoid belt, especially in heavily infected populations. Thus, analysis of female reproductive condition, female fecundity and age-related reproductive contribution were conducted only for samples collected from macrophytes.

All females in the investigated populations were classified according to the following conditions: (1) presence or absence of embryos in the brood pouch, and (2) presence of mature trematode infection. Thus, the females were divided into 4 groups:

Group I: uninfected females without embryos in the brood pouch. In general, the youngest of these females ( 2 to 3 yr old) had undeveloped oviducts. Females more than 3 years old had well developed gonoducts and unfertilized eggs in the proximal part of the pallial oviduct but never contained eggs or embryos in the brood pouch.

Group II: uninfected gravid females. They had completely developed oviducts containing unfertilized eggs. The brood pouch content consisted of cleaving eggs, veliger-like and trochophore-like embryos and juveniles mixed in various proportions.
Table 5. Littorina saxatilis. Infection prevalences of females and males in populations with low (N1, N2), intermeduate (M) and high $\left(\mathrm{H}_{1}, \mathrm{H} 2\right)$ infection prevalences. Substrates: $F$, fucoids; G. gravel; $S$, stone surfaces. For 0 and $100 \%$ values the number of examıned snails is given in parentheses

\begin{tabular}{|ccrc|}
\hline \multirow{2}{*}{$\begin{array}{c}\text { Population } \\
\text { N1 }\end{array}$} & Substrate & \multicolumn{2}{c|}{$\begin{array}{c}\text { Infection prevalence }(\%) \\
\text { Females } \\
\text { Males }\end{array}$} \\
\hline & F & $0.8 \pm 0.53$ & $1.6 \pm 0.93$ \\
& G & $2.8 \pm 2.75$ & $3.1 \pm 3.06$ \\
N2 & S & $1.7 \pm 1.68$ & $6.2 \pm 4.26$ \\
& F & $4.4 \pm 1.43$ & $3.5 \pm 1.54$ \\
& G & $7.7 \pm 7.39$ & $0(10)$ \\
M & S & $15.0 \pm 4.87$ & $0.5 \pm 7.03$ \\
& F & $14.2 \pm 3.10$ & $10.1 \pm 2.65$ \\
& G & $5.4 \pm 3.72$ & $12.1 \pm 4.01$ \\
& S & $12.7 \pm 4.20$ & $14.9 \pm 5.19$ \\
& F & $56.2 \pm 4.84$ & $58.8 \pm 5.50$ \\
& G & $74.1 \pm 5.75$ & $81.8 \pm 5.34$ \\
& S & $100(103)$ & $100(93)$ \\
H2 & F & $51.9 \pm 3.07$ & $50.0 \pm 3.79$ \\
& G & $57.6 \pm 6.43$ & $52.5 \pm 7.89$ \\
& S & $96.9 \pm 1.95$ & $92.5 \pm 3.22$ \\
\hline
\end{tabular}

Group III: infected barren females. These females had degenerated oviducts. We never found eggs or embryos in the oviducts and brood pouches of group III females.

Group IV: infected gravid females. Females had degenerated oviducts which never contained eggs. The brood pouch contained 1 to 3 (rarely up to 10) completely developed juveniles. Embryos on the early stages of development (eggs to veligers) were never found in group IV females.

For all populations the relative abundance of group I was the highest for 2 to 3 yr old females and than decreased with the age of molluscs. However, females in this group could be found among all the age classes (Fig. 6).

The first appearance of the group II females was observed in 3 (populations N1, N2, H2) or 4 (populations $M$ and $H 1$ ) yr old snails. Contrary to group $I_{\text {, the }}$ relative abundance of uninfected gravid females generally increases with snail age. However, in heavily infected populations this increase was less marked (Fig. 6). In general, abundance of group II in the total of females more than 2 yr old approached $50 \%$ in populations $N 1, N 2$ and $M$ and was significantly lower in populations $\mathrm{H} 1$ and $\mathrm{H} 2(\mathrm{p}<0.01$ ) (Table 6).

In populations $\mathrm{N} 1$ and $\mathrm{N} 2$, the number of the group III females was small and their presence was not related to age $(p>0.05)$ (Fig. 6). In the other populations, relative abundance of the group III females was greatest in older $(\mathrm{H} 2)$ or middle-aged females (M, H1) (Fig. 6). 


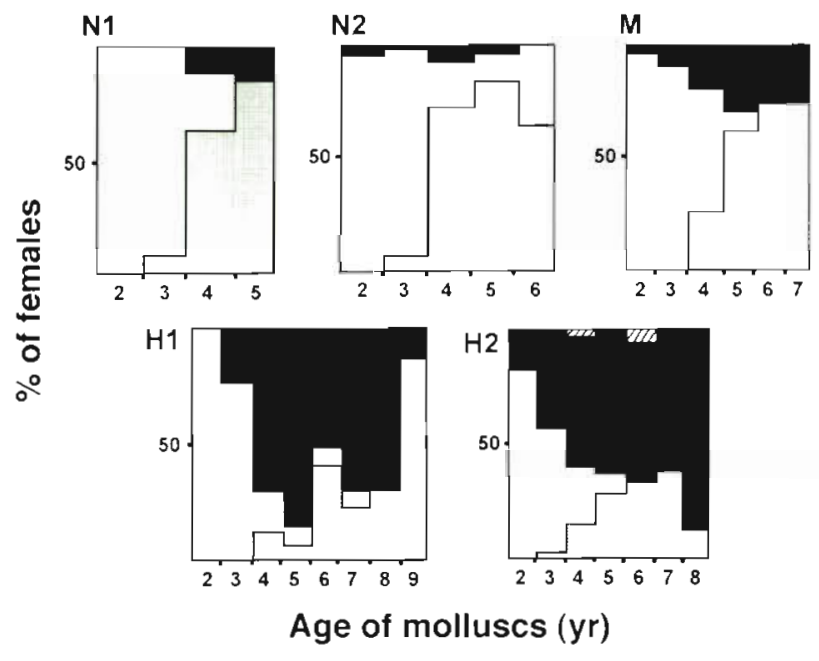

Fig. 6. Littorina saxatilis. Reproductive condition of females in L. saxatilis populations with low (N1, N2), intermediate (M) and high (H1, H2) infection prevalences. Proportion (\%) of females of the given group in each age class is represented with corresponding areas: white areas: uninfected barren females (group I); shaded areas: uninfected gravid females (group II); black areas: infected barren females (group III); hatched areas: infected 'gravid' females (group IV). Total height of each diagram equals $100 \%$

Group IV females were found only in the $\mathrm{H} 2$ population and did not exceed $2 \%$. Their presence was not clearly correlated with age $(p>0.05)($ Fig. 6)

\section{Female fecundity}

In general, female fecundity tended to increase with the age of females (Table 7). However, within-population variations in the numbers of embryos between females of the same age were large, so that only in populations $\mathrm{N} 2$ and $\mathrm{M}$ was the influence of female age on fecundity significant ( $\mathrm{p}<0.01$ ) (Table 8 ).

As was shown by ANOVA, infection level in the population of origin significantly affected female fecundity $(p<0.01)$ (Table 9). Variation by factor 'Infection level
Table 6. Littorina saxatilis. Abundance $( \pm S E)$ of uninfected gravid females among the total of adult ( 3 and more yr old) females in populations with low (N1, N2), intermediate (M) and high $(\mathrm{H} 1, \mathrm{H} 2)$ infection prevalences

\begin{tabular}{|ccccc|}
\hline N1 & N2 & M & H1 & H2 \\
\hline $53.1 \pm 6.92$ & $47.7 \pm 3.92$ & $44.6 \pm 4.48$ & $28.9 \pm 4.47$ & $17.8 \pm 2.35$ \\
\hline
\end{tabular}

Table 7. Littorina saxatilis. Average age-specific fecundity (number of embryos per female) in populations with low (N1, $\mathrm{N} 2$ ), intermediate (M) and high (H1) infection prevalences

\begin{tabular}{|c|c|c|c|}
\hline Population & Age & No. of females & Average fecundity \\
\hline \multirow{5}{*}{ N1 } & 3 & 4 & $22.0 \pm 2.27$ \\
\hline & 4 & 22 & $21.8 \pm 2.78$ \\
\hline & 5 & 14 & $22.8 \pm 3.96$ \\
\hline & 6 & 7 & $23.8 \pm 3.43$ \\
\hline & 7 & 1 & 55.0 \\
\hline \multirow[t]{4}{*}{ N2 } & 3 & 6 & $10.8 \pm 3.52$ \\
\hline & 4 & 37 & $16.6 \pm 1.90$ \\
\hline & 5 & 20 & $31.1 \pm 4.08$ \\
\hline & 6 & 2 & $42.5 \pm 8.50$ \\
\hline \multirow[t]{6}{*}{$\mathrm{M}$} & 4 & 14 & $44.4 \pm 5.38$ \\
\hline & 5 & 25 & $71.3 \pm 6.01$ \\
\hline & 6 & 17 & $81.1 \pm 10.62$ \\
\hline & 7 & 4 & $108.5 \pm 14.22$ \\
\hline & 4 & 1 & 5.0 \\
\hline & 5 & 1 & 139.0 \\
\hline \multirow[t]{5}{*}{$\mathrm{H1}$} & 6 & 9 & $139.7 \pm 18.27$ \\
\hline & 7 & 4 & $110.8 \pm 22.89$ \\
\hline & 8 & 6 & $156.7 \pm 16.75$ \\
\hline & 9 & 6 & $220.8 \pm 42.99$ \\
\hline & 10 & 1 & 81.0 \\
\hline
\end{tabular}

in the population of origin' was $14.3 \%$ of the total. Female fecundity increased with the degree of trematode infection, being the lowest in populations N1 and $\mathrm{N} 2$, intermediate in population $\mathrm{M}$ and the highest in populations $\mathrm{H} 1$ (Table 10). The same tendency was found when age-specific fecundity was compared (Table 7).

Table 8. Littorina saxatilis. ANOVA. Influence of female age on fecundity in populations with low (N1, N2), intermediate (M) and high ( $\mathrm{H} 1)$ infection prevalences. All ages found in the given population were included in the analysis

\begin{tabular}{|c|c|c|c|c|c|c|c|c|}
\hline \multirow[t]{2}{*}{ Population } & \multicolumn{2}{|c|}{ Factorial } & \multicolumn{2}{|c|}{ Residual } & \multicolumn{2}{|c|}{ Total } & \multirow[t]{2}{*}{$F$} & \multirow[t]{2}{*}{$\mathrm{p}$} \\
\hline & SS & $\mathrm{df}$ & SS & df & SS & df & & \\
\hline N1 & 1063.99 & (4) & 6988.49 & $(43)$ & 8052.48 & $(47)$ & 1.637 & $>0.10$ \\
\hline N2 & 4296.16 & (3) & 11654.05 & (61) & 15950.21 & (64) & 7.496 & $<0.01$ \\
\hline$M$ & 17220.95 & (3) & 60037.23 & (56) & 77258.18 & (59) & 5.354 & $<0.01$ \\
\hline $\mathrm{H} 1$ & 63397.51 & (6) & 94166.92 & (21) & 157564.43 & $(27)$ & 2.356 & $>0.05$ \\
\hline
\end{tabular}


Table 9. Littorina saxatilis. ANOVA. Estimation of the influence of infection level in the population of origin on female fecundity

\begin{tabular}{lrrrrr|}
\hline Source of variation & SS & df & $F$ & $p$ \\
\hline $\begin{array}{l}\text { Covariate: } \\
\text { Age of female }\end{array}$ & 331682.15 & 1 & 294.598 & $<0.01$ \\
Factor effect: & & & & \\
Infection level & 92597.56 & 2 & 41.122 & $<0.01$ \\
Residual & 221798.83 & 197 & & \\
Total & 646078.54 & 200 & & \\
\hline
\end{tabular}

Table 10. Littorina saxatilis. ANOVA. Average fecundity ( $\pm \mathrm{SE}$ ) for all females in populations with different infection prevalences

\begin{tabular}{|lrcc|}
\hline $\begin{array}{l}\text { Infection } \\
\text { level }\end{array}$ & $\begin{array}{c}\text { No. of } \\
\text { females }\end{array}$ & $\begin{array}{c}\text { Average } \\
\text { fecundity }\end{array}$ & $95 \% \mathrm{CI}$ \\
\hline Low (N1, N2) & 113 & $22.1 \pm 1.38$ & $15.85-28.30$ \\
Medium (M) & 60 & $70.3 \pm 4.67$ & $61.74-78.83$ \\
High (H1) & 28 & $149.6 \pm 14.44$ & $137.13-162.15$ \\
\hline
\end{tabular}

\section{Relative contribution of the different age groups of females into embryo production}

In populations $\mathrm{N} 1, \mathrm{~N} 2$ and $\mathrm{M}$, the main contribution to the reproduction was made by 4 and 5 yr old females. They produced 60 to $90 \%$ of the total quantity of embryos in the populations (Fig. 7). In population $\mathrm{H} 1$ females more than 6 yr old produced more than $60 \%$ of the total quantity of embryos (Fig. 7).

\section{DISCUSSION}

This study has shown that the demographic structure of Littorina saxatilis populations is very complicated and variable. Both intra- and interpopulation variations were observed. Intrapopulation variations (such as differences in population density and age structure on various substrata) are probably caused by the heterogeneity of microhabitat conditions which has been adequately discussed by other authors (Mikhailova et al. 1988, Sergievsky \& Granovitch 1989, Granovitch 1990) and will not be addressed in this discussion. The question of how the factor of trematode infection influences the demography of $L$. saxatilis population requires interpopulation comparison.

Population density observed in the investigated populations varied considerably (from hundreds to more than 2000 ind. $\mathrm{m}^{-2}$ ). This is the usual situation for Littorina saxatilis populations in the White Sea (Galak-

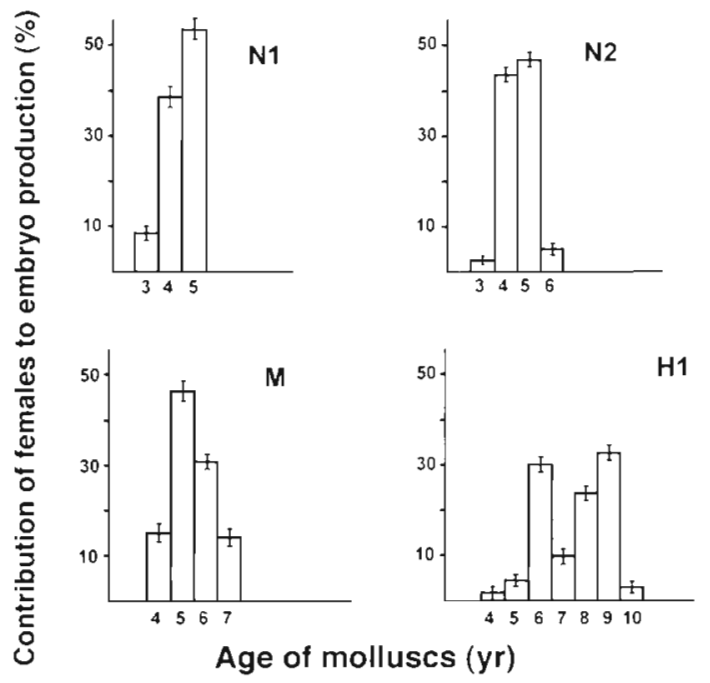

Fig. 7. Littorina saxatilis. Relative contribution ( $\pm \mathrm{SE}$ ) of different age groups of females into embryo production in populations with low (N1, N2), intermediate (M) and high ( $\mathrm{H} 1)$ infection prevalences

tionov \& Dobrovolsky 1984, Granovitch 1990) and generally conforms with the data obtained for different parts of the species range (Matveeva 1974).

Age structure is another general demographic parameter which reflects efficiency of recruitment. Age structure appears to depend on infection prevalence of the population. In control and moderately infected populations, age structure was characterized by a high percentage of young snails and a stepwise decrease of relative quantity of the older snails. This pattern, with little variation, was found in the studied populations for at least several years (Sokolova pers. obs.). This kind of age-frequency distribution has been theoretically predicted for populations with balanced mortality and birth rates (Pianka 1981).

In contrast, heavily infected populations possessed a different age structure pattern having a deficiency of juveniles. These results suggest insufficient recruitment of juveniles caused by suppression of the reproductive potential in the host population by severe trematode infection. It is evident that prolonged poor recruitment would lead to population extinction. However, heavily infected populations at $\mathrm{H} 1$ and $\mathrm{H} 2$ locations are known to persist for rather long periods (at least 12 yr) (Granovitch 1990, 1992). Therefore, successful recruitment in these locations probably occurs, at least in some years. Thus, the question arises: Which mechanisms are responsible for successful repopulation of Littorina saxatilis under conditions of severe parasitic pressure?

One of the common features found in heavily infected populations of Littorina saxatilis is increased 
infection prevalence of snails on gravel and stone surfaces. This phenomenon was previously described for L. saxatilis populations in the White and Barents Seas (Galaktionov \& Marasaiev 1986, Sergievsky \& Granovitch 1989, Granovitch 1990). Special experimental studies on $L$. saxatilis infected by microphallids of 'pygmaeus' group (group A in present study) showed that microhabitat distribution of infected periwinkles is a result of parasite-induced modification of host behavior (Granovitch 1990, Granovitch \& Lyzen 1990). Probably, the trematode-induced movement of infected snails into gravel and stone habitats results in an increase of concentration of uninfected periwinkles on the macrophytes. This may enhance probability for uninfected (i.e. potentially fertile) individuals of both sexes to meet.

The total sex ratio in the investigated populations of Littorina saxatilis was close to $1: 1$ or slightly biased towards females. The most striking feature of the agerelated sex ratio alterations was the decrease in the number of males with age. Trematode infection appears to have no influence either on the total sex ratio, or on age-related sex ratio changes in these populations.

The age of female maturation (the first appearance of embryos in the brood pouch) slightly varied in the studied populations but typically occurred at 3 to $4 \mathrm{yr}$ of age. There was no correlation between the age of female maturation and infection prevalence.

Longevity of periwinkles was found to be higher in the heavily infected populations. This fact may seem surprising considering that trematodes, as a rule, show a negative influence on the molluscan host survival (Hurd 1990). It appears unlikely that trematode infection should have a direct causal relation on increased longevity. Nevertheless, high longevity in heavily infected Littorina saxatilis populations may be an adaptation to prolong duration of the reproductive period of females and to increase the number of old females with high fecundity. As a result, the total production of the offspring in a heavily infected population can potentially increase. This hypothesis requires more testing, but support for this hypothesis is suggested by the presented data on age-specific fecundity and age-related contribution to embryo production in the heavily infected population of $L$. saxatilis

In general, about one-half of the total of adult ( 3 and more yr old) females were gravid in the populations with low and moderate infection levels. In the heavily infected populations the abundances of uninfected gravid females were much lower, approaching onethird to one-fifth of the total of adult females.

Fecundity of Littorina saxatilis tended to increase with the age of female, which is typical for L. saxatilis throughout its range (Matveeva 1974, Hughes \&
Roberts 1980a, b, Hughes \& Answer 1982, Gallardo \& Gotting 1985). However, age-specific fecundity may vary in different environments (Begon et al. 1989). Trematode infection was found to correlate with fecundity of $L$. saxatilis. Average fecundity of uninfected females increased with the increase of infection level in the population of origin. This tendency also can be observed on age-specific fecundity that was highest in populations with severe infection, intermediate in the moderately infected population and lowest in the populations with low infection levels. As trematode infection was found to have a strong negative effect on the number of gravid females in L. saxatilis populations, increased age-specific fecundity in heavily infected populations may be regarded as the adaptive response to the infection.

Superposition of the number of gravid females in different age groups and the age-specific fecundity allows estimation of the contribution of each age group to reproduction.

The main investment to embryo production in Littorina saxatilis populations with low and moderate infection levels belonged to the 5 yr old females. The contribution of the oldest females to offspring production was not large despite their high age-specific fecundity. This was caused by the low abundance of the oldest females in these populations. A similar pattern of agerelated contribution to reproduction has been reported for L. saxatilis populations by Galaktionov (1985) and Granovitch \& Sergievsky (1990). In contrast, in the heavily infected population ( $\mathrm{H} 1$ ) the relative investment of the oldest females to embryo production was large: more than one-half of the total embryo number was found in the brood pouches of females of 7 and more yr old. Evidently, this can be attributed to extremely high fecundity and relatively high abundance of the old females in this population.

These results contradict those of previous studies in Littorina littorea (see Robson \& Williams 1971) and Ilyanassa obsoleta (see Curtis \& Hurd 1983) that suggested the repopulation was mainly supported by the youngest mature snails. These conclusions were based on the analysis of age-prevalence data which showed that among adults, infection prevalences were lowest for the young snails (those at their first reproductive season) and increased with age of molluscs. As was suggested, low infection prevalences of snails at their first reproductive season provide a sort of 'fenestra temporalis' (Curtis \& Hurd 1983) for repopulation in sites with severe infection. However, it is not the case with the heavily infected population of $L$. saxatilis. Though the age-prevalence pattern was similar to those reported for $L$. littorea and $I$. obsoleta, contribution of the youngest ( $4 \mathrm{yr}$ old) adult females to the embryo production was small. This indicates that 
analysis of age-prevalence data alone cannot provide evidence supporting the theory of age-related 'significance' of females for repopulation, especially for species with high longevity, complicated age structure and age-dependent fecundity changes.

The comparative analysis of the demographic structure of Littorina saxatilis populations showed that in spite of great variability, there are some general features of demography that are typical for all populations regardless of their infection level, namely, total sex ratio close to $1: 1$, decrease in male abundance with age and female maturation at 3 to $4 \mathrm{yr}$ of age. Other demographic parameters undergo significant alterations that are correlated with trematode infection. Trematode infection results in the decrease in the number of snails able to reproduce and, therefore, suppresses offspring recruitment. High longevity and increased fecundity of females in heavily infected populations is probably an adaptive response supporting population persistence urder conditions of severe infection pressure.

Acknowledgements. The author is grateful to Dr A. Granovitch and Dr S. Sergievsky for considerable help and advice during the field work and to the anonymous reviewers for questions and comments that helped to improve the manuscript.

\section{LITERATURE CITED}

Begon M, Harper JL, Townsend CR (1989) Ecology. Individuals, populations and communities. Mir, Moscow (in Russian)

Curtis LA, Hurd LE (1983) Age, sex and parasites: spatial heterogeneity in sandflat population of Ilyanassa obsoleta. Ecology 64:819-828

Dobrovolsky AA, Galaktionov KV, Mukhamedov GK, Singha BK, Tikhomirov IA (1983) Parthenogenetic generations of trematodes. Trudy Leningradskogo obshchestva estestvoispytateley (Proceedings of Naturalists Society of Leningrad) 82(4) (in Russian)

Fleis J (1989) Statistical methods for investigation of proportions and ratios. Finansy i statistika, Moscow (in Russian)

Galaktionov KV (1985) Infection prevalence of males and females of molluses from Littorina genus (Gastropoda, Prosobranchia) by trematode parthenites at the Barents Sea shore. Parazitologiya 19(3):213-219 (in Russian)

Galaktionov KV, Dobrovolsky AA.(1984) An experience of population analysis of the trematode life cycles using microphallids of 'pygmaeus' group (Trematoda: Microphallidae) as an example. In: Polsnsky Ju I (ed) Ecologoparazitologicheskiye issledovaniya severnykh morey (Ecological-parasitological investigations of the north seas). Nauka Apatity:8-41 (in Russian)

Galaktionov KV, Marasaiev SF (1986) Some peculiarities of spatial distribution of the infection prevalence in molluscs of Littorina genus by the parthenogenetic stages of trematodes in the intertidal zone of the Barents and the White seas. Vestnik Leningradskogo Gosudarstvennogo Universiteta (Controutions from the Leningrad State University)
3(1):88-90 (in Russian)

Gallardo CS, Gotting KJ (1985) Reproduktionsbiologische Untersuchungen an drei Littorna Arten der sudlichen Nordsee. Helgoländer Meeresunters 39:165-186

Granovitch Al (1990) Populational-parasitological analysis of the White Sea intertidal molluscs Littorina saxatilis (Olivi) (Gastropoda: Prosobranchia). PhD thesis, Moscow State University (in Russian)

Granovitch Al (1992) The effect of trematode infection on the population structure o: Littorina saxatilis (Olwivi in the White Sea. In: Grahame J, Mill PF, Reid DG (eds) Proceedings of the Third International Symposium on Littorinid Biology. Malaco.ogical Society of London, London, p 255-263

Granovitch AI, Lyzen IM (1990) Trematode infection as factor determining spatial distribution in Littorina saxatilis populations. In: Roitman VA (ed) Faktory regulatsii populatsionnykh protsessov u gelmintov (Factors of regulation of populational processes in helminths). Nauka, Moscow (in Russian)

Granovitch AI, Sergievsky SO (1990) Estimation of reproductive structure of Littonna saxatilis (Olivi) (Gastropoda, Prosobranchia) populations in the White Sea. Zool $\mathrm{Zh}$ 69(8):32-41 (in Russian!

Hughes RN, Answer P (1982) Growth, spawning and trematode infection of Littorina littorea (L.) from an exposed shore in North Wales. J mollusc Stud 48:321-330

Hughes RN, Roberts DJ (1980a) Growth and reproductive rates of Littorina neritoides (L.) in North Wales. J mar biol Ass UK 60:591-599

Hughes RN, Roberts DJ (1980b) Reproductive effort of winkles (Littorina spp.) with contrasted methods of reproduction. Oecologia 47:130-136

Hurd H (1990) Physiological and behavioural interactions between parasites and invertebrate hosts. In: Adv Parasitol 29:271-318

James BL (1968a) The occurrence of Parvatrema homoeotecnum James, 1964 (Trematoda: Gymnophallidae) in a population of Littorina saxatilis tenebrosa (Mont.). I nat Hist 2:21-37

James BL (1968b) Studies on the life-cycle of Miscrophallus pygmaeus (Levinsen, 1881) (Trematoda: Microphallidae). $\mathrm{J}$ nat Hist 2:155-172

Janson K (1983) Selection and migration in two distinct phenotypes of Littorina saxatılis in Sweden. Oecologia 59: $58-61$

Janson K, Ward RD (1.984) Microgeographic variation in allozyme and shell characters in Littorina saxatilis Olivi (Prosobranchia: Littorin:dae). Biol J Linn Soc 22:289-307

Lauckner G (1980) Diseases of Mollusca: Gastropoda. In: Kinne $O$ (ed) Diseases of marine animals, Vol 1. General aspects, Protozoa to Gastropoda. John Wiley and Sons, Chichester, p 311-424

Matveeva TA (1974) Ecology and life cycles of common gastropod species in the Barents and the White Seas. In: Bykhovsky BE (ed) Issledovaniya fauny morey. Sezonnye yavleniya v zhyzni Belogo I Barentseva morey (Invest1gations of marne fauna. Seasonal phenomena in the White and Barents Seas), Vol 13(21). Nauka, Leningrad, p 65-190 (In Russian)

Mikhailova NA, Granovitch A., Sergievsky SO (1988) The influence of trematode invasion on the microhabitat distribution of molluscs Littorina obtusata and L. saxatilis. Parasitologia 22(5):398-407 (in Russian)

Planka E (1981) Evolutionary ecology. Mir، Moscow (in Russian)

Pohley WJ (1976) Relationships among three species of Litto- 
rina and their larval digenea. Mar Biol 37:179-186

Robson EM, Williams IC (1971) Relationships of some species of Digened with marine prosobranch Littorina Jittorea (L.).

2. The effect of larval Digenea on the reproductive biology of L.littorea. J Helminthol 45:145-159

Sergievsky SO, Granovitch Al (1989) Spatial heterogeneity in

Responsible Subject Editor: A. K. Sparks, Seattle

Washington, USA the population structure of intertidal mollusc Littorina saxatilis (Olivi). Trudy Zoologicheskogo Instituta AN SSSR (Proceedings of Zoological Institute of Acad. Sci. of USSR) 203:146-168 (in Russian)

Urbakh V Yu (1964) Biometric methods. Naukd, Moscow (in Russian)

Manuscript first recesved: October 12,1993

Revised version accepted: October 12, 1994 